\title{
KEUTAMAAN ISTIGFAR: KANDUNGAN MAKNA ISTIGFAR TERHADAP HADIST RIWAYAT IBN MAJAH
}

\author{
M Syahar Ma'arif \\ IAIN Ponorogo \\ maarifsyahar84@gmail.com
}

\begin{abstract}
Abstrak
In addition to the Qur'anic verses explaining the importance of istighfar, many hadith also suggested it. There is even hadith of Ibn Majah explaining that for anyone who is accustomed to istighfar, he will be gifted by Allah as God will make every sorrow a relief, and from every difficulty a way out, and give him a sustenance through unexpected ways. From this research found: (1) Ibn Majah's hadith is dhaif(weak). It is based on the assessment of the critics of the hadith which says that al-Hakam ibn Mus'ab is majhul (unknown); however (2) Ibn Majah's matn al-hadith (essence) is acceptable. It is proven when the hadith is studied in wider detail, it is also in accordance with the Qur'an. Not contrary and even in line with what is in it. As well as other hadiths, many hadiths that encouraged every Muslim to celebrate istighfar, and this was exemplified by the Messenger of Allah in his daily life. Of course, there are many verses that explain the wisdom He has revealed to those who practice istighfar, such as the reception of grace, the removal of sins, the conquest, the triumph of good and so on.
\end{abstract}

Keywords: Istighfar, Getting used

Selain ayat al-Qur'an yang menjelaskan anjuran istighfar, banyak sekali hadith yang menganjurkannya juga. Bahkan ada yang berisi penjelasan bahwa bagi siapa saja yang membiasakan istighfar, maka ia akan diberikan keutamaan oleh Allah seperti Allah akan menjadikan dari setiap kesedihan kelonggaran, dan dari setiap kesempitan jalan keluar dan memberi rizki kepadanya dari arah yang tidak disangka-sangka.

Dari penelitian ini adalah : (1) Hadits Ibn Ma>jah tentang keutamaan membiasakan istighfar tersebut bersanad $d l o{ }^{\prime} i>f$. Hal ini berdasar atas penilaian para kritikus hadith yang mengatakan bahwa al-H\}akam ibn Mus\}' ab adalah majhu>l (2) Hadith Ibn Ma>jah terkait adalah bisa diterima maknanya. Ini terbukti, ketika hadith tersebut dikaji dengan rinci sekalipun, ia juga sesuai dengan al-Qur'an. Tidak bertentangan dan bahkan sejalan dengan apa yang ada di dalamnya. Hadith-pun juga demikian, banyak sekali hadith yang menganjurkan setiap muslim untuk membiasakan istighfar, dan ini dicontohkan pula oleh Rasulullah saw. dalam kehidupan sehari-hari beliau. Terbukti juga, banyak ayat yang menjelaskan akan hikmah yang diturunkan oleh-Nya kepada mereka yang membiasakan istighfar, seperti turunnya rahmat, dosa yang dihapus, diberikan kemenangan, keburukan diganti kebaikan dan sebagainya.

\section{Kata kunci: Istighfar, Membiasakan}




\section{Pendahuluan}

Pada hakikatnya manusia terlahir dalam kondisi fitrah (suci). ${ }^{1}$ Ia tidak membawa dosa keturunan, meski ia terlahir dari hubungan haram kedua orang tua. Namun demikian dalam perjalanan kehidupannya, banyak manusia yang melakukan perbuatan yang berada dalam larangan Allah, sehingga ia pun mendapatkan dosa atas perbuatannya tersebut.

Islam menegaskan bahwa tidak ada seseorang yang memikul dosa, kecuali dosanya sendiri. Dosa, sebagai akibat buruk atau jahat, menurut ajaran Islam pasti dirasakan oleh pelakunya. Bila di dunia ini, pelakunya belum merasakan akibat buruk atau jahat dari perbuatan dosa itu, niscaya kelak di akhirat pasti ia rasakan sebagai suatu yang membuatnya menderita atau merasa pahit dan tidak berbahagia. Berdasarkan keterangan dari al-Qur'an, siapa yang dosanya lebih berat dari pahala perbuatan baiknya, niscaya akan menderita dalam neraka, sedang bila pahala lebih berat dari dosa yang ia lakukan, niscaya ia akan bahagia dalam surga. Kejatuhan Adam kedalam dosa dan kemudian taubatnya diterima Tuhan, menunjukkan bahwa setiap manusia memiliki potensi untuk jatuh ke dalam dosa, disamping memiliki potensi untuk bisa bertaubat dan konsisten dalam ketaatan. Kendati Adam pernah berdosa atau orang tua berlumuran dosa, namun setiap anak yang dilahirkan, lahir dalam keadaan fitrah, seperti fitrah Adam sebelum jatuh kepada dosa. ${ }^{2}$

Katakanlah: "Apakah aku akan mencari Tuhan selain Allah, Padahal Dia adalah Tuhan bagi segala sesuatu. dan tidaklah seorang membuat dosa melainkan kemudharatannya kembali kepada dirinya sendiri; dan seorang yang berdosa tidak akan memikul dosa orang lain. kemudian kepada Tuhanmulah kamu kembali, dan akan diberitakan-Nya kepadamu apa yang kamu perselisihkan." (Qs. al-An'a>m: 164).

\footnotetext{
${ }^{1}$ Dari segi bahasa, kata fit\}rah terambil dari akar kata al-fat\}r yang berarti belahan, dan dari makna ini lahir makna-makna lain, diantaranya "penciptaan" atau "kejadian". Konon sahabat Nabi Ibnu Abbas tidak tahu persis makna kata $f a t\} i>r$ pada ayat-ayat yang berbicara tentang penciptaan langit dan bumi sampai ia mendengar pertengkaran tentang kepemilikan satu sumur. Salah seorang mereka berkata: "Ana fat\}artuhu". Ibnu Abbas kemudian memahami kalimat ini dalam arti, "Saya yang membuatnya pertama kali". Dan dari situ beliau memahami bahwa kata ini digunakan untuk penciptaan atau kejadian sejak awal. Dengan demikian kata M. Quraish Shihab, Membumikan al-Quran (Bandung: Mizan,1996), 284. Fit\}rah manusia berarti kejadiannya sejak semula atau bawan sejak lahirnya.

"Maka hadapkanlah wajahmu dengan lurus kepada agama (Allah); (tetaplah atas) fitrah Allah yang telah menciptakan manusia menurut fitrah itu. Tidak ada perubahan pada fitrah Allah. (Itulah) agama yang lurus; tetapi kebanyakan manusia tidak mengetahui" (Qs. al-Ru>m : 30)

2 Harun Nasution dkk, "Dosa" dalam Ensiklopedia Islam Indonesia IAIN Syarif Hidayatullah (Jakarta: Djambatan, 1992), 224-225.
} 
Berkaitan dengan perbuatan manusia, yang di dalamnya terdapat perilaku baik dan buruk, sedangkan taubat ${ }^{3}$ merupakan solusi terbaik untuk menebus dosa-dosa ${ }^{4}$ yang telah diperbuat, dan bahkan hal tersebut sangat jelas diperintahkan dalam alQur'an $^{5}$ dan hadith ${ }^{6}$. Akan tetapi mengapa manusia seringkali lalai atau bahkan tidak menghiraukan anjuran tersebut.

Kata taubat ${ }^{7}$ dalam bahasa Arab kerapkali disebut al-nadm (penyesalan). Kata-kata ini juga digunakan dalam hadith. Di samping itu menariknya masih banyak terma-terma lain yang bermakna taubat yang juga tecantum dalam hadith dan setiap kata itu menjelaskan aneka ragam bentuk taubat seperti, $a l$-ina $>b a h^{8}$, dan istighfa $>r$ (memohon ampunan).

Bertaubat dari dosa-dosa dengan cara kembali kepada Allah swt. adalah modal untuk memperoleh keuntungan di dunia dan di akhirat. Ini tercermin terhadap pilihan yang diberikan oleh Allah swt, yaitu: pertama, menjadi orang yang beruntung dengan bertaubat. Kedua, menjadi orang yang tidak beruntung (rugi) dengan tidak bertaubat, sebagaimana perintah Allah swt. kepada hamba-Nya agar selalu bertaubat:

\footnotetext{
${ }^{3}$ Tobat dalam bahasa Indonesia disebut dengan tobat atau taubat berasal dari kata $\mathrm{t}-\mathrm{w}-\mathrm{b}, \mathrm{yatu}>\mathrm{bu}$, taubatan, dalam beberapa kamus diartikan 'a>da yang berarti kembali, raja'a yang berarti kembali dan ana>ba juga memiliki makna sama yaitu kembali. Lihat: Muhammad Murtad\}a al Zubaidy, Ta>j al 'Aru>sh jilid I, 13360 (Mesir: al-Mut\}aba'a>t al-Khairiyyah bi al-Jama>liyyah, T.th.),161 dan lihat Jama>1 al-Din Muhammad Ibn Mukarram Ibn Manzur, Lisa>n al- 'Arab, Jilid I (Beirut: Da>r al- S\{adr, t. th), 233.

${ }^{4}$ Menurut Jumhur ulama, Allah SWT. tidak menentukan berapa jumlah istilah untuk dosa dalam al-Qur'an, namun dosa dapat diklasifikasikan menjadi dua, yaitu dosa besar (kaba>ir) dan dosa kecil. Lihat Q.S. An-Nisa>' (4) : 31. 41. Maka Bagaimanakah (halnya orang kafir nanti), apabila Kami mendatangkan seseorang saksi (Rasul) dari tiap-tiap umat dan Kami mendatangkan kamu (Muhammad) sebagai saksi atas mereka itu (sebagai umatmu).

5 "Dan bertaubatlah kalian semua kepada Allah, wahai orang-orang mukmin, agar kalian mendapat keberuntungan." (QS. An-Nu>r: 31) dan juga "Wahai orang-orang yang beriman bertaubatlah kalian kepada Allah dengan taubat yang sebenar-benarnya" (QS.at-Tahri>m: 8)

6 "Wahai sekalian manusia, bertaubatlah kepada Allah SWT, karena sesungguhnya aku bertaubat kepada Allah SWT dalam satu hari sebanyak seratus kali". (Hadi>s\ diriwayatkan oleh Muslim dari alAghar al-Muzni)

7 Taubat dalam arti tawbah nas $\}$ > ha > adalah usaha manusia untuk menyesali kesalahan-kesalahannya yang lalu dan tidak akan mengulangi lagi di waktu yang akan datang. Taubat adalah bagian dari usaha manusia untuk menyucikan jiwa dari sifat-sifat yang tidak terpuji yang diharapkan berimplikasi terhadap tingkah laku manusia dalam kehidupan sehari-hari, baik tingkah laku manusia yang berhubungan dengan Tuhannya, Rasul, orang tua, sesama atau hubungan manusia dengan lingkungannya. Al- Ha>rith bin Asad alMuha>sibi>, al-Taubah (Tk.: Da>r al- I'tis\}a>m, T.t.), 51.

${ }^{8}$ Yaitu kembali kepada Allah berulang kali, walaupun tidak didahului dosa sebelumnya. Suatu keadaan dimana taubat sudah tidak terbatas lagi oleh derajat dan tahapannya tetapi dalam rangka menuju keparipurnaan iman itu sendiri. Lihat dalam Imam al-Ghazali, Raudah; Taman Jiwa Kaum Sufi, terj. M. Luqman Hakim, cet II (Surabaya: Risalah Gusti, 1995), 125.

Taubat adalah suatu masalah yang banyak diungkapkan dalam al-Qur'an, pembicaraan mengenai taubat itu sendiri muncul dalam beberapa surat dan terulang sebanyak 87 kali yang tersebar dalam 70 ayat. Di atas adalah ungkapan taubat yang diungkapkan dengan akar kata t-w-b. Louis Ma'luf, Al-Munji>d fi> al-Lughah wa al'Ala $>m$, (Beiru>t: Da $>$ r al-Masyriq,Tt.), 20.
} 
"Dan bertaubatlah kamu sekalian kepada Allah, Hai orang-orang yang beriman supaya kamu beruntung." (Qs. al-Nu>r: 31). ${ }^{9}$

Taubat bukan hanya sebagai penghapus dosa tetapi sebagai sarana untuk mendekatkan diri kepada Allah swt., karena itu sekalipun tidak berdosa, manusia diperintahkan untuk bertaubat. Nabi Muhammad saw. sendiri sekalipun sudah terpelihara dari segala dosa, beliau tetap bertaubat dan meminta ampun (istighfa $>r$ ) kepada Allah swt. Ini tercermin dari sabda beliau yang diriwayatkan oleh Ima>m Bukha>ri.

"Demi Allah, aku beristighfar kepada Allah dan bertaubat kepada-Nya dalam sehari lebih dari tujuh puluh kali (HR. Bukha>ri). ${ }^{10}$

Bahkan dalam salah satu hadith yang lain disebutkan, bahwa jika seseorang yang mau membiasakan dirinya dengan istighfa $>r$, maka Allah akan memberikan kepadanya tiga hal. Pertama, Allah akan memberikan keluasan dari setiap kesempitan yang ia hadapi. Kedua, dari setiap kesedihan ada jalan keluar dan ketiga, memberikan rizqi yang tidak disangka-sangka.

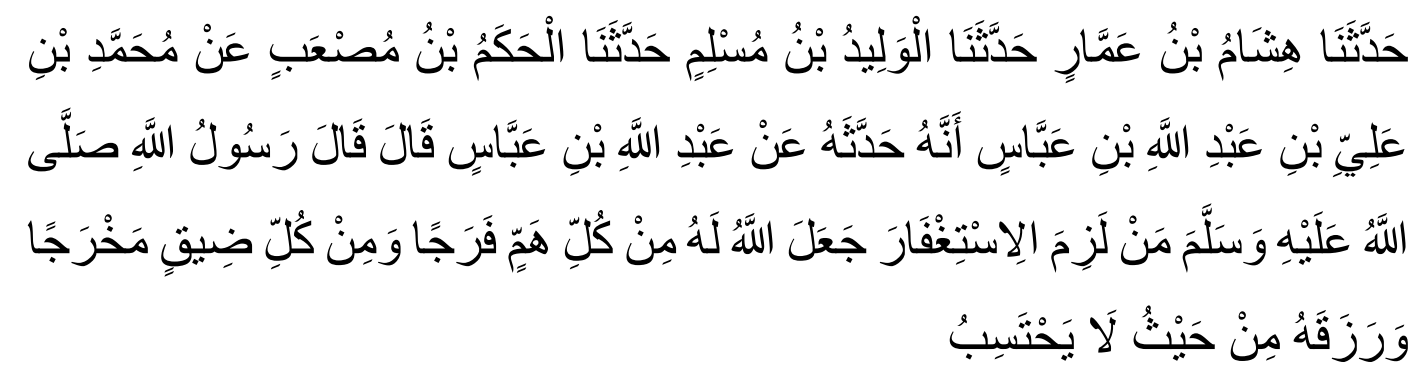

Telah menceritakan kepada kami Hisha>m bin 'Amma>r telah menceritakan kepada kami al-Wali>d bin Muslim telah menceritakan kepada kami al-H\}akam bin Mus\}'ab dari Muh\}ammad bin Ali> bin Abd Alla>h bin 'Abba $>s$ bahwa dia menceritakan kepadanya dari 'Abd Alla $>$ h bin 'Abba $>$ s dia berkata; Rasulullah saw. bersabda: "Barang siapa yang menekuni istighfar, Allah akan menjadikan dari setiap kesedihan kelonggaran, dan dari setiap kesempitan jalan keluar dan memberi rizki kepadanya dari arah yang tidak disangka-sangka." (HR. Ibn Ma>jah).

Sebagaimana sebelumnya, hadith tersebut memberikan penjelasan bahwa jika seseorang mau membiasakan dirinya dengan membaca istighfar maka Allah akan

\footnotetext{
${ }^{9}$ Departemen Agama RI, al-Qur'an dan Terjemahannya, cet, III (Semarang: Tanjungmas Inti, Tt.), 549.

${ }^{10}$ Ima>m al-Bukha>ri>, Shahih Bukhari (Mesir: Maktabah al-Iman, Tt.), 1288. Hadith no. 6307.
} 
memberikan kepadanya tiga keutamaan. Tentu saja hal tersebut berasalan. Bisa jadi hal tersebut karena istiqomahnya atau karena maknanya. Jika karena istiqomahnya kemudian hal tersebut mendatangkan kecintaan Allah pada pelakunya, maka hal tersebut bisa dilakukan siapa saja tanpa harus banyak mencurahkan pikiran dalam melakukannya. Jika karena alasan kedua, karena makna yang terkandung di dalamnya, tentu perlu mendapat perhatian lebih. Jika demikian halnya, kandungan makna apa saja yang ada dalam istighfar, sehingga orang yang senantiasa mengamalkannya akan diberikan keutamaan oleh Allah?

\section{Metode Penelitian}

Penelitian ini adalah penelitian pustaka, maka secara garis besar metode penelitian ini adalah sebagai berikut:

Pendekatan dan Jenis Penelitian

Penelitian ini merupakan penelitian libary, karena data-data penelitian ini hampir keseluruhannya adalah data-data kepustakaan.

a. Langkah Penelitian Sanad

Dalam meneliti sanad hadith, langkah yang diambil adalah pertama, dengan takhri>j al-hjadi>th tersebut dalam keseluruhan kutub al-tis'ah. Sedangkan metode takhrïj hadith dapat dilakukan di antaranya mencari dengan menggunakan nama sahabat, lafal awal dari matan hadith, kata-kata dalam matan hadith, kata kunci (tema) hadith, kamus hadith dan lain-lain. ${ }^{11}$

Langkah selanjutnya adalah dengan $i$ 'tiba $>r$. Yang dimaksud dengan $i^{\prime} t i b a>r$ adalah upaya penyertaan sanad-sanad dalam meneliti suatu hadith yang pada sanadnya tampak hanya terdapat seorang periwayat saja dengan menyertakan sanad lain akan diketahui adakah periwayat-periwayat lain atau tidak. ${ }^{12}$ Dan langkah terakhir adalah mencari kualitas masing-masing perawi, sehingga akan diketahui apakah sanadnya terputus atau tidak?

b. Langkah Penelitian Matan

Menurut Syuhudi Ismail, al-Qur'an telah menjelaskan fungsi serta tugas Nabi Muhammad, baik sebagai rah\}matan li al- ' $a>l a m i<n$, juga sebagai manusia

\footnotetext{
${ }^{11}$ Lebih jelasnya dapat dibaca dalam M. Syuhudi Isma'il, Cara Praktis Mencari Hadis Nabi (Jakarta: Bulan Bintang, 1991), 49-70.

${ }^{12}$ Lihat Muhammad Tahhan, Taisi>r Must\}alah\} al-H\}adith (Surabaya: Syirkah Bungkul Indah, tt.), 15. dari kegiatan ini diterapkan ada tidaknya suatu pendukung baik berupa sya $>$ hid maupun muttabi'.
} 
biasa. Oleh karenanya apa yang lahir dari ekspresi Nabi saw. di samping memiliki muatan universal, pada saat yang sama, ekspresi tersebut juga muncul dari diri Muhammad sebagai manusia biasa yang hidup pada konteks waktu dan wilayah yang terbatas.

Nabi juga hidup bersama yang lain (berinteraksi) baik sebagai keluarga, tetangga, kepala negara, da'i dan sebagainya, sehingga kompleksitas diri yang integral dalam dirinya turut mewarnai apa yang terlahir dari aktualisasi hidupnya.

Berdasarkan argumen itulah maka hadith Nabi sarat akan nilai universal, temporal dan lokal, pada sisi lain sarat akan fungsi beliau sebagai Rasul, kepala negara, pemimpin masyarakat, panglima perang, hakim, pribadi dan lainnya. Hal ini pulalah yang harus diperhatikan ketika memahami hadith tersebut. ${ }^{13}$

Syuhudi Ismail juga menjelaskan bahwa apa yang terekam dari aktualisasi Nabi yang dikenal kemudian dengan hadith hadith Nabawi merupakan teks teks yang kemudian dapat dipahami dari makna yang tersurat, tetapi sekaligus dapat dipahami pada konteks apa teks tersebut muncul. Itulah sebabnya, ada beberapa hadith yang tepat ketika dipahami secara teks, tetapi ada pula yang kurang tepat kalau tidak dipahami konteksnya. Hal inilah yang melahirkan pemahaman tekstual dan kontekstual. ${ }^{14}$

Lebih lanjut Syuhudi memetakan bentuk matan hadith yang menuntut cara pemahaman yang berbeda-beda masing-masing bentuk tersebut, di antaranya berbentuk kalimat pendek yang padat makna (jawa<mi' al-kala>m), bentuk tamsil, bentuk ungkapan simbolik, bentuk dialog, dan ungkapan analogi. ${ }^{15}$

Peta lainnya adalah memahami hadith berdasarkan peran dan fungsi Muhammad, apakah sebagai Rasulullah, pemimpin negara, pribadi dan sebagainya. ${ }^{16}$ Peta lainnya adalah petunjuk hadith Nabi SAW yang dibubungkan dengan sebab yang mengiringi baik secara langsung tergambar dalam hadith maupun tidak, baik sebab khusus ataupun umum. ${ }^{17}$

Dan terakhir Syuhudi memberikan teknik penyelesaian dalam memahami hadith-hadith yang tampak saling bertentangan. ${ }^{18}$ Hadith tersebut dinilai mukhtalif

\footnotetext{
${ }^{13}$ Syuhudi Ismail, Hadis Nabi, 3-5.

${ }^{14}$ Ibid., 6-7.

15 Ibid., 9.

${ }^{16}$ Ibid., 33-34.

${ }^{17}$ Ibid., 49.

18 Ibid., 71.

${ }^{19}$ Ibid., 73.
} 
(bertentangan) bila memiliki kualitas yang setara sementara redaksinya bertolak belakang. Oleh karena itu, penelitian terhadap sanad menjadi penting sebelum diklaim hadith itu mukhtalif.

b. Langkah Memahami Hadith Nabi

Menurut al-Qardawi>, hadith Nabi saw. memiliki kedudukan yang penting dalam ajaran Islam, karenanya umat harus melihatnya melalui metode yang tepat yaitu bingkai ajaran Islam yang menyeluruh (komprehensif), keseimbangan dan memudahkan. ${ }^{19}$ Karenanya pula dalam memahami sunnah Nabi melalui hadith-hadithnya tersebut harus menghindarkan diri dari upaya pemahaman atau penafsiran yang ekstrem, tanpa dasar atau dengan pengalihan (manipulasi). ${ }^{20}$

Berdasarkan hal tersebut di atas, maka seseorang yang hendak memahami hadith haruslah melalui tahapan-tahapan sebagai berikut:

1) Memahami al-Sunnah dengan berpedoman pada al-Qur'an. ${ }^{21}$

2) Mengumpulkan hadith-hadith dalam satu topik ${ }^{22}$

3) Memadukan atau mentarjih antara hadith-hadith yang kontradiktif. ${ }^{23}$

4) Memahami hadith dengan mempertimbangkan latar belakangnya, situasi dan kondisinya ketika diucapkan serta tujuannya. ${ }^{24}$

5) Membedakan antara sarana yang berubah-ubah dan sasaran yang tetap. ${ }^{25}$

6) Membedakan antara ungkapan yang bermakna sebenarnya dan yang bersifat majaz dalam memahami hadith Nabi. ${ }^{26}$

7) Membedakan antara hadith yang memuat alam gaib dengan alam yang kasat mata. $^{27}$

8) Memastikan makna dan konotasi kata-kata dalam hadith. ${ }^{28}$

\section{Pembahasan}

\section{A. Makna Hadith}

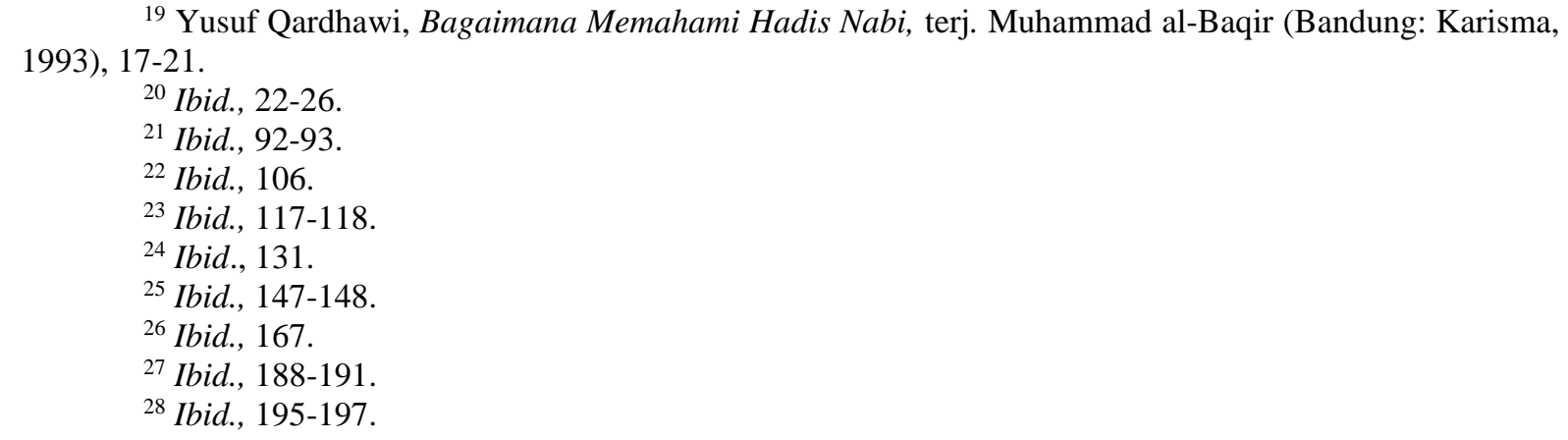


Untuk memudahkan dalam bab ini, maka dituliskan kembali teks hadith terkait penelitian ini.

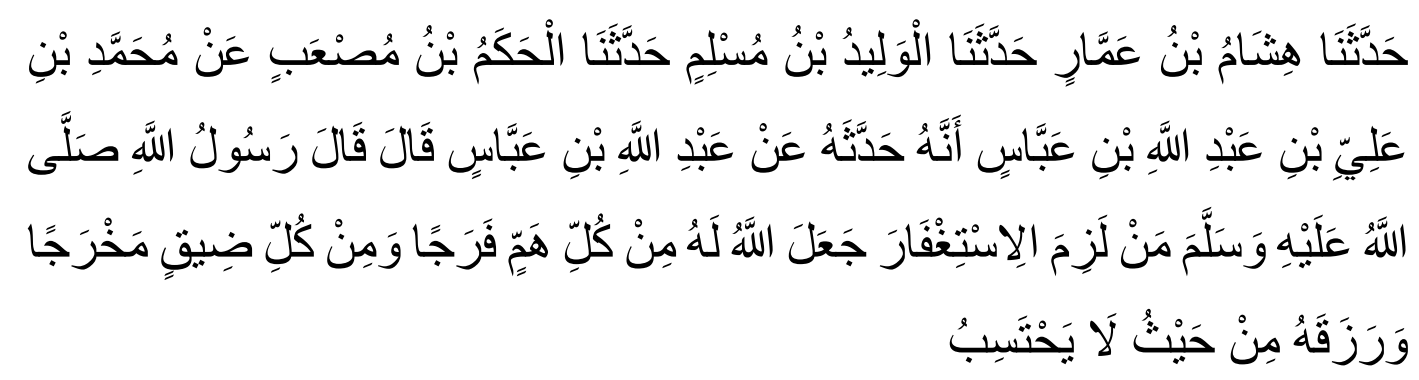

Telah menceritakan kepada kami Hisha>m bin 'Amma>r telah menceritakan kepada kami al-Wali>d bin Muslim telah menceritakan kepada kami al-H\}akam bin Mus\}'ab dari Muh\}ammad bin Ali> bin Abd Alla $>$ h bin 'Abba $>$ s bahwa dia menceritakan kepadanya dari 'Abd Alla>h bin 'Abba>s dia berkata; Rasulullah saw. bersabda: "Barang siapa yang menekuni istighfar, Allah akan menjadikan dari setiap kesedihan kelonggaran, dan dari setiap kesempitan jalan keluar dan memberi rizki kepadanya dari arah yang tidak disangka-sangka." (HR. Ibn Ma>jah).

Untuk memahami hadith tersebut, maka perlu diambil kata kunci dari matan hadith tersebut, dimana kata kunci tersebut jika diulas akan mampu memberikan penjelasan lebih atas rumusan masalah yang dibuat. Berikut ini penjelasan kalimat per kalimat dari matan tersebut.

1. Makna kata man lazima

Hadis di atas diawali perkataan Nabi SAW. man lazima (siapa yang membiasakan, melazimkan), mengandung pengertian siapa saja (umat Muhammad sendiri ataupun bukan, orang yang ada pada masa Nabi ataupun sesudahnya) dan siapa saja (tanpa terikat oleh apapun khususnya setelah ucapan ini diluncurkan), untuk tidak menyatakan (baik secara lisan maupun tertulis).

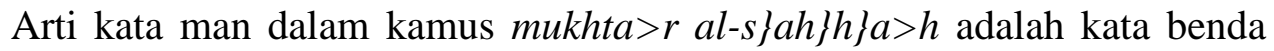
(ism) yang cocok digunakan untuk mukha>t\}ab, termasuk ism yang samar dan tidak jelas maknanya. Kata man adalah lafadh yang berbentuk satu kata saja, namun bermakna jama'ah. Sebagaimana ayat Allah

Dan Kami telah tundukkan (pula kepada Sulaiman) segolongan syaitansyaitan yang menyelam (ke dalam laut) untuknya dan mengerjakan pekerjaan selain daripada itu, dan adalah Kami memelihara mereka itu. (Qs. alanbiya $\left.>^{\prime}: 82\right)$. 
Kata tersebut menempati empat hal; pertama, untuk istifha $>m$ (meminta penjelasan), contoh مَن عندلك (siapa yang berada disisimu?). Kedua, sebagai khabar , contoh رأيت كَن عندلك (saya melihat orang ada disisimu). Ketiga, sebagai jaza> , (balasan), contoh أُكرمه مَن يُكرمني (saya memuliakan orang yang memuliakan saya). Keempat, menjadi ism nakirah (kata benda yang masih umum), contoh مررت بِمَن مُحسن (aku berjalan bersama orang yang baik). Hal ini senada dengan apa yang ada dalam Kamus al-Munawwir, bahwa kata من شر ط جازم adalah (isim syarat). ${ }^{29}$

Dalam matan tersebut, kata man menempati syarat, sesuai dengan empat tempat di atas, maka kata man dalam matan hadith tersebut menempati jaza>' (balasan).

Sebagai ilustrasi berikut contoh yang sama susunannya dengan matan hadith tersebut: (إن تذهب أذهب) Artinya : Jika kamu pergi, saya pergi. تذهب) fi'il syarat (أذهب) jawab / jazak syarat. Fi'il yang pertama dinamakan fi'il syarat dan yang kedua di namakan jawab / jaza' syarat.

Selain itu kata tersebut sangat umum cakupannya. Siapapun. Asal dia mau mengerjakan, maka dia mendapatkan jaza>. Atau dalam konteks hadits tersebut, siapapun yang mau membiasakan membaca istighfar (syarat), maka dia akan mendapatkan balasan (jaza>') berupa dihilangkannya oleh Allah akan kesedihan dengan kelonggaran, dan dari setiap kesempitan jalan keluar dan memberi rizki kepadanya dari arah yang tidak disangka-sangka.

Dalam kamus al-mu'jam al-wasi>t\} disebutkan, bahwa makna kata lazima adalah menetapi dan melazimkan. Jika kata lazima digabungkan dengan kata benda yang menjadi objek (maf' $u>l$ bih) maka maknanya menjadi menetapi dan melazimkan objek tersebut. Dalam hadith tersebut, kata lazima disambungkan dengan kata istighfa>r. Maka maknanya menjadi menetapi dan melazimkan istighfar.

2. Makna al-istighfar

${ }^{29}$ Ah \}mad Warson Munawwir, Kamus al-Munawwir (Surabaya: Pustaka Progressif, 1997), 1361. 
Dilihat dari asal kata, istighfar berasal dari kata غَفَر بَغْفِر (ghofaro yaghfiru) إستفعل yang bermakna mengampuni atau memaafkan. Lafazh ini mengikuti wazan (istaf'ala yastaf'ilu istif'al), sehingga istighfar mengandung arti meminta ampunan.

"Istighfar berasal dari pada kata ghafara maknanya 'satara' dan 'ghat't\}' $a$ ' menutup dan/atau menekan. Dengan istighfar manusia berusaha menutup atau menekan dorongan perasaan dan pikiran-pikiran yang menghalangi jalan menuju Allah Ta'ala." Kata (اسْتَغْفَرَ ) dalam bahasa arab bermakna meminta maghfirah

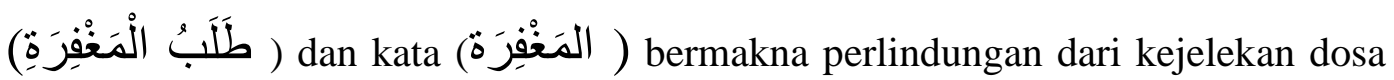
atau penghapusan dari dosa dan pergantiannya.

Syeikh Ibnu Taimiyah berkata: Kata (الإسنتِغْفَارَ) dalam bahasa arab bermakna meminta maghfirah (طَلَبُ الََْغْفَرَةِ dan kata (المَغْفِرَة) bermakna perlindungan dari kejelekan dosa. Kata al-maghfirah (المَغْفِرَة punya makna

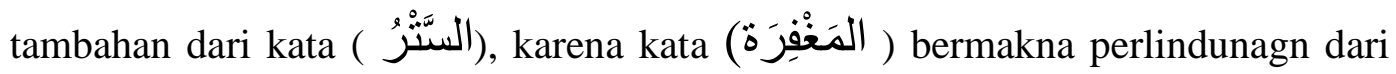
kejelekan dosa, sehingga seorang hamba tidak disiksa lagi. Orang yang diampuni dosanya tidak akan disiksa. Sedangkan sekedar ditutupi (dosa tersebut), masih ada kemungkinan disiksa dalam batin dan orang yang masih disiksa dalam batin atau lahiriyahnya maka ia belum diampuni. ${ }^{30}$

Al-Nawa>wi menjelaskan bahwa kata ghafara (غفر) yang sering diterjemahkan "mengampuni” asalnya bermakna menutup (ستر).

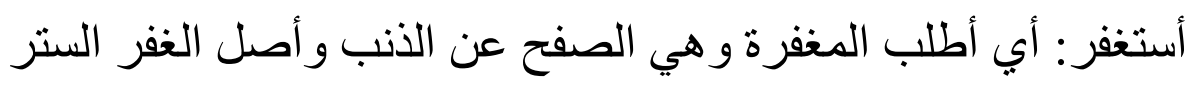

Istighfar adalah mencari pengampunan, yaitu membersihkan diri dari dosa.

Asal makna "ghafara" adalah menutup.

\footnotetext{
${ }^{30}$ Ibnu Taimiyah, Majmu' Fatawa 10/317.

${ }^{31}$ Kata al-Ghufra $>$ n terambil dari kata ghafara yang pada mulanya berarti 'menutup'. Rambut putih yang disemir hingga tertutup putihnya disebutkan dengan ghafara asy-sya'ra. Dari akar kata yang sama, lahir kata ghifarah, yang berarti 'sepotong kain yang menghalangi kerudung sehingga tidak ternoda oleh minyak rambut.' Maghfirah Ilahi adalah "Perlindungan-Nya dari siksa neraka." M. Quraish Shihab, Wawasan Alquran: Tafsir Tematik Atas Pelbagai Persoalan Umat (Bandung: Mizan, 1998), 332.

${ }^{32}$ Abi> Zakariyya> Muh\}y al-Di>n al-Nawa>wiy, Nuzhat al-Muttaqîn fî Sharh al-Riyâdl al-Shâlihîn (Beirut:Muassisah al-Risa>lah, 1977), 33
} 
Kalimat "astaghfiru” artinya hamba mencari (memohon) maghfirah, dengan maksud al-s\}afh $\} u$ dari dosa (agar catatan ketidakbaikan dibuang dan diganti lembaran baru yang putih bersih). ${ }^{33}$

3. Makna ja'zala Alla $>$ hu lahu>

Secara kaidah nahwiyyah, kata ja'ala (menjadikan) dalam kalimat ja'zala Alla> hu lahu> (Allah telah menjadikan baginya), kata tersebut menggunakan fi'il mad $i>$ (kata kerja lampau). Seakan maksud kalimat tersebut, pada dasarnya keutamaan yang diberikan Allah kepada mereka yang membiasakan istighfar adalah keutamaan yang sudah pasti. Bahkan al-Qur'an pun juga menjelaskannya. Sehingga, siapapun dia, yang membiasakan istighfar maka Allah akan melimpahkan keutamaannya kepadanya.

4. Makna kata min kuli hammin farajan

Kata hamm berarti kegelisahan, kesusahan. Sedangkan kata farajan berasal dari kata faraja (membuka, melapangkan, merenggangkan, menghilangkan, meringankan, melapangkan). Jika keduannya disambungkan, maka akan berarti orang yang membiasakan istighfar, terlepas siapapun dia, maka akan akan menjadikan baginya kelapangan, dan diganti dengan kemudahan. Perlu diingat, baik kata hamm dan farajan keduanya, sama-sama menggunakan kata umum (nakirah) sehingga makna keduanya juga mencangkup segala sesuatu yang mampu dicakup oleh keduanya. Apapun itu yang bersifat menyusahkan, menyedihkan, Allah akan menggantinya dengan apapun yang menjadikan lawan bagi keduanya, sehingga orang tersebut tidak akan merasa sedih dan susah lagi.

Alasan menggunakan kata umum tersebut sesuai dengan karakter setiap orang yang berbeda satu sama lain. Kesedihan satu orang mungkin bisa diobati dengan satu hal, namun belum tentu cocok bagi yang lain. Sehingga sangat tepatlah jika keduannya menggunakan ism nakirah. Tolchah Hasan mengatakan bahwa Allah akan memberikan jalan keluar terbaik pada orang itu atas setiap kesulitan yang ditemui. ${ }^{34}$

${ }^{33}$ Istighfar merupakan bentuk dzikir yang mempunyai keutamaan baik untuk memperoleh keutamaan duniawi maupun ukhrawi. Oleh karena itu Al Baha Khauli istighfar merupakan kunci drizki dari langit baik bersifat spiritual maupun material.

“ Dan hendaklah kamu meminta ampun kepada Tuhanmu dan bertaubat kepada-Nya. (jika kamu mengerjakan yang demikian), niscaya dia akan memberi kenikmatan yang baik (terus menerus) kepadamu sampai kepada waktu yang Telah ditentukan dan dia akan memberikan kepada tiap-tiap orang yang mem-punyai keutamaan (balasan) ke-utamaannya. jika kamu berpaling, Maka Sesungguhnya Aku takut kamu akan ditimpa siksa hari kiamat" (Qs. Hu>d: 3).

${ }^{34}$ M. Tolchah Hasan, Dinamika Kehidupan Religius (Jakarta: Lintafariska Putra, 2004), 93. 
5. Makna min kulli $d\}$ i> qin makhrajan

Dalam Kamus al-Munawwir disebutkan, bahwa kata $d\} i>q$ sama artinya dengan kata $d$; a'f (kesempitan, kesengsaraan dan kesulitan). ${ }^{35}$ kata makhrajan berasal dari kata kharaja-yakhriju-khuru>j (keluar). Kata makhrajan mengikut wazan maf'alun yang menempati z\}araf maka>n (kata yang menunjukkan tempat). Sehingga kata tersebut bermakna tempat keluar/ jalan keluar. Jika kedua kalimat tersebut disambungkan, maknanya menjadi siapun yang membiasakan, melazimkan istighfar maka Allah akan menjadikan bagi apapun yang ia rasakan, baik itu kesempitan rizqi, kesengsaraan karena kemiskinan, kekeringan dan kesulitan apapun, maka Allah akan menghilangkan semua itu, melapangkannya, dan diganti dengan kemudahan dan jalan keluar. Dalam matan hadith tersebut, jalan keluar yang dimaksud belum jelas. Masih umum. Sehingga bisa jadi jalan keluar yang dimaksud berasal dari Allah secara langsung, atau melalui perantara manusia. Singkatnya, Allah akan memberikan pemecahan terhadap semua keprihatinan yang dialami. ${ }^{36}$

6. Makna wa razaqahu> min h\}aithu la> yah\}tasibu

Kata tersebut, menurut Tolchah Hasan, berarti Allah akan memberikan jalan keluar bagi orang tersebut, dari arah yang tidak pernah ia pikirkan sebelumnya atau ia sangka. Beliau mencontohkan, misalnya seorang pegawai dengan penghasilan Rp. 250.000/ bulan. Dihitung secara rasional, tidak mungkin gaji sekecil itu bisa menghidupi keluarga dengan tiga anak, hidup di tengah kota, membayar SPP anak, biaya kesehatan, makan, rekening listrik dan lainnya. Tapi kenyataannya ia bisa hidup, bahkan bisa usaha kecil-kecilan. Ini bentuk contoh rizqi yang tidak disangka. ${ }^{37}$

\section{B. Makna Istighfar}

Dosa sebagaimana digambarkan oleh Rasulullah ibarat noda hitam di dalam hati. Bila seseorang melepaskan diri dari dosa, memohon ampun dan bertobat, hatinya akan cemerlang. Tapi bila ia mengulangi perbuatan dosa, maka noda hitam itu akan bertambah hingga meliputi hatinya. Oleh karena itu, kemudian disyariatkan bagi semua

\footnotetext{
${ }^{35}$ Muh \}ammad Warson, al-Munawwir, 825.

${ }^{36}$ M. Tolchah Hasan, Dinamika Kehidupan Religius, 93.

${ }^{37}$ Ibid.
} 
orang untuk memperbanyak istighfar. ${ }^{38}$ Para ulama bersepakat tentang wajibnya bertaubat dari dosa kecil maupun dosa besar. ${ }^{39}$

Ima>m al-Ghazali mengatakan bahwa tidak ada dosa kecil kalau dilakukan terus menerus, dan tidak ada dosa besar bila seseorang beristighfar. ${ }^{40}$ Taubat erat kaitannya dengan istighfar (mohon ampunan) yaitu perlindungan, pertolongan serta ampunan dengan menundukkan jiwa, hati dan pikiran kepada Allah swt., seraya mohon ampun dari segala dosa. Taubat dan istighfar bukan hanya memohon ampunan dari dosa-dosa yang dilakukan manusia tetapi juga sarana mendekatkan diri kepada Allah. ${ }^{41}$ Kaitan antara taubat dan istighfar adalah tidak dapat dikatakan taubat jika tanpa istigfar, atau dengan kata lain istighfar adalah bagian dari taubat itu sendiri.

Banyak sekali bentuk ungkapan yang sering dilantunkan oleh kaum muslimin dalam kesehariannya, diantaranya sebagai berikut:

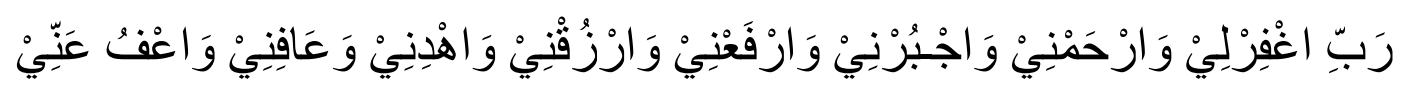

Wahai Tuhan hamba, ampunilah hamba, rahmatilah hamba, cukupilah hamba, angkatlah derajat hamba, berilah hamba (kecukupan) rezeki, berilah hamba hidayah, anugerahilah hamba 'afiat (kesehatan yang digunakan untuk hal-hal yang Engkau ridhai), dan maafkanlah segala kesalahan hamba

Demikianlah doa yang senantiasa kita baca ketika duduk di antara dua sujud. Di dalam doa tersebut, terkandung permintaan "ampun" (اغْفِرْ ) di awal serta permohonan “maaf" (اعْفْ ) di akhir doa. Apa perbedaan "ampun" dan "maaf”? 42

${ }^{38}$ Muhammad Nursani, Mencari Mutiara di Dasar Hati, (Jakarta; Tarbawi Press,2005), 81.

39 Pada beberapa bahasa memiliki sinonim, meskipun makna sinonim tersebut ada pada sebagian sisi kandungan maknanya saja, tidak pada keseluruhannya. Pada kata t-w-b misalnya, kata ini mempunyai sinonim dalam penggunaan taubat yaitu a-w-b yang berarti kembali. Dalam al-Munjid, kata ini juga diartikan seperti di atas yaitu "kembali". Tidak berbeda dengan kata di atas kata nawab juga merupakan sinonim kata taubah yang artinya juga sama yaitu "kembali” F. M. Denny, Kosa Kata Taubat dalam al-Qur'an: Arah dan Sikap, terj. M. Yusron, (dalam "Suara Muhammadiyah”, No. IV. th. 1997, ke. 82), 44.

$40 \mathrm{Abu}>\mathrm{H}$ \}amid bin Muh\}ammad al-Ghaza>li>,. Mukhtasyar Diya>' Ulu>m al-di>n,(terj) Irwan Kunyawan. (Bandung:Mizan. 1996), 306-207.

${ }^{41}$ Ibrahim al Dasuki,al-Taubah Tajdi>d Da>im li al-H\}aya >t dalam Khutbat al-Jum'ati wa al-'I>dain (Kairo : Dar Al Maarif, 1986), 60.

42 Taubat baru dianggap sah dan dapat menghapus dosa, bilamana meme-nuhi syarat-syarat yang telah ditentukan. Oleh karena itu taubat yang dapat diterima oleh Allah adalah taubat yang memenuhi kriteria-kriteria sebagai berikut :

1. Menyesali dan meninggalkan dengan segera kesalahan-kesalahan yang telah dilakukan.

2. Menjauhi dan tidak mengulangi kesalahan-kesalahan dan perbuatan-perbuatan dosa.

3. Mengikuti perbuatan-perbuatan dosa itu dengan perbuatan-perbuatan baik, sebagaimana sabda Rasulullah:"Iringilah perbuatan jahat dengan perbuatan baik, itu akan meng-hapus dosanya" (HR Turmudzi dari Abi Dzar) 
Di Kamus Besar Bahasa Indonesia, tidak ada perbedaan antara "ampun" dan “maaf”. Berikut ini penjelasannya:

Ampun lampun/ $n$ 1. pembebasan dr tuntutan krn melakukan kesalahan atau kekeliruan; maaf: ia selalu berdoa dan memohon-atas segala dosa dan kesalahannya; 2. kata yg menyatakan rasa heran kesal:-, anak ini nakalnya bukan main; 3. cak bukan main: aduh baunya,-, deh;

ma.af $n 1$ pembebasan seseorang dr hukuman (tuntutan, denda, dsb) krn suatu kesalahan; ampun:minta -; 2 ungkapan permintaan ampun atau penyesalan:-, saya datang terlambat; 3ungkapan permintaan izin untuk melakukan sesuatu:-, bolehkah saya bertanya;

Menurut kebiasaan masyarakat, kata "maaf" digunakan kepada sesama manusia, sedangkan kata "ampun" untuk Allah SWT. Hal ini terbukti saat lebaran (Idul Fitri) misalnya, belum pernah peneliti temukan seseorang berkata kepada temannya, "ampuni kesalahanku, ya..." atau "mohon ampun lahir dan batin..." Mungkin bila benar-benar dipraktikkan, sungguh terasa sangat janggal. ${ }^{43}$

Dalam al-Quran kata Ghaffar $^{44}$ terulang sebanyak lima kali, dua di antaranya berdiri sendiri, yakni dalam QS. Nuh (71): 10 dan QS. Thaha (20): 82:

Tiga syarat diatas menyangkut dosa terhadap Allah SWT sedangkan untuk dosa kepada sesama manusia, ditambah lagi syarat yang keempat yaitu: kalau dosa itu menyangkut harta-benda harus dikembalikan kepada pemiliknya. Jika pemiliknya sudah tidak ada lagi maka hendaklah dikembalikan kepada ahli warisnya. Kalau dosa itu menyangkut kehormatan hendaklah meminta maaf.

43 Bertolak dari kata maaf. Dalam bahasa Indonesia, subjeknya disebut pemaaf. Pemaaf berarti orang yang rela memberi maaf kepada orang lain. Sikap pemaaf berarti sikap suka memaafkan kesalahan orang lain tanpa sedikit pun ada rasa benci dan keinginan untuk membalasnya. Dalam bahasa Arab sikap pemaaf disebut al-'afw yang juga memiliki arti bertambah (berlebih), penghapusan, ampun, atu anugerah (Munawwir, 1984: 1020). Dalam al-Quran kata al-'afw disebut sebanyak dua kali, yakni dalam QS. al-Baqarah (2): 219 dan QS. al-A'raf (7): 199. Dalam QS. al-Baqarah (2): 219 Allah Swt. berfirman:

Dan mereka bertanya kepadamu tentang apa yang mereka nafkahkan. Katakanlah: "Yang berlebih dari keperluan". (QS. al-Baqarah (2): 219).

Dari makna berlebih atau bertambah tersebut, kata al-'afw maknanya berkembang menjadi menghapuskan atau memaafkan. Dalam QS. al-A'raf (7): 199. “Jadilah engkau pemaaf dan suruhlah orang mengerjakan yang ma`ruf, serta berpalinglah daripada orang-orang yang bodoh.”

Jadi, makna memaafkan inilah yang kemudian menjadi makna baku dari kata al-'afw. Kata al-'Afw juga merupakan salah satu dari sifat atau asma Allah yang berarti dzat yang Maha Pemaaf (QS. al-Mujadilah (58): 2).

${ }^{44}$ Perlu dimengerti pula akan adanya kesamaan kata ghafara dan 'afwu. Di buku "“Menyingkap 'Tabir Ilahi-Al-Asmâ' al-Husnâ dalam Perspektifal-Qur'an”, M. Quraish Shihab menjelaskan bahwa di beberapa kamus dinyatakan pada dasarnya kata 'afwu berarti menghapus (habis tiada berbekas), membinasakan dan mencabut akar sesuatu. Allah adalah al-'Afuww, yakni Dia yang menghapus kesalahan hamba-hamba-Nya, serta memaafkan pelanggaran-pelanggaran mereka.

Sifat ini mirip dengan sifat al-Ghafûr, hanya saja menurut Imam Ghazali, pemaafan Allah lebih tinggi nilainya dari maghfirah. Bukankah kata 'afwu mengandung makna menghapus, mencabut akar sesuatu, membinasakan dan sebagainya, sedang kata ghafûr terambil dari akar kata yang berarti menutup?Sesuatu yang ditutup pada hakikatnya tetap wujud hanya tidak terlihat, sedangkan yang dihapus, hilang, kalau pun ada tersisa, paling hanya bekas-bekasnya. 
Maka aku katakan kepada mereka: 'Mohonlah ampun kepada Tuhanmu, sesungguhnya Dia adalah Maha Pengampun-,

Dan Sesungguhnya aku Maha Pengampun bagi orang yang bertaubat, beriman, beramal saleh, kemudian tetap di jalan yang benar.

Jadi, bila kita ber-istighfar, misalnya dengan kalimat أَسْتَغْفِرْ الله , hal itu berarti kita memohon, "Ya Allah, buanglah catatan amal tidak baik hamba dan gantilah dengan lembaran baru yang putih bersih."

Ibnul 'Arabi berpendapat bahwa kalimat اللَّهُمَ اغْفِرْ لِيْ juga dipahami dalam arti, "Ya Allah, perbaikilah keadaan hamba."

Dengan pengertian istighfar ini, para ulama menasihatkan agar kita tidak merasa diri lebih baik dibandingkan orang lain. Bahkan terhadap orang yang berbuat dosa besar pun, kita dilarang. Siapa tahu dia bertaubat dan Allah menerima taubatnya, sehingga kondisinya seperti orang yang tidak pernah punya kesalahan karena telah dibuang catatan kesalahannya serta dibuka lembaran baru (al-s \}afh \}u).

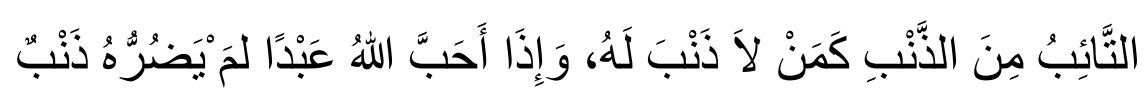

"Seorang yang taubat dari dosa seperti orang yang tidak punya dosa, dan jika Allah mencintai seorang hamba, pasti dosa tidak akan membahayakannya." (HR Ibnu Majah)

Sebagai tambahan, ada tiga pengertian dari sifat pengampun Allah, tiga sifat ketuhanan yang terpisah tetapi saling berkaitan satu sama lain, yaitu al-Ghaffār, al-Ghāfir, dan al-Ghafūr.

Selain ghafara dan 'afwu, terdapat kata al-s\}afh\}. Pakar bahasa Al-Qur'an, al-Raghib al-Asfahani, menulis dalam Mufradât-nya bahwa apa yang dinamai al-s\}afh\}, yang antara lain berarti "lembaran yang terhampar" memberi kesan bahwa yang melakukannya membuka lembaran baru -putih bersih- belum pernah dipakai, apalagi dinodai oleh sesuatu yang dihapus. Dengan demikian, al-s $\}$ afh $\}$ lebih dalam maknanya dibandingkan ghafaradan 'afwu.

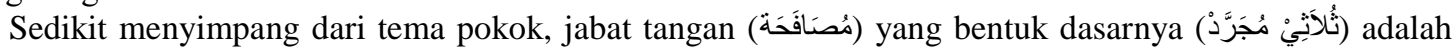
shafaha (صفح) dianjurkan dalam agama. Di sebuah hadits disebutkan:

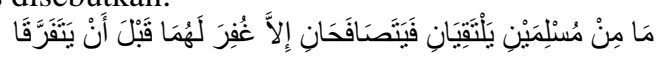

Tidaklah dua orang muslim bertemu lalu berjabat tangan melainkan keduanya akan diampuni (dosanya) sebelum mereka berpisah. (HR Abu Daud, Tirmidzi dan Ibnu Majah)

Hasan al-Bashri menuturkan, "Berjabat tangan dapat menambah kasih sayang." Penulis pernah ditanya, "Istighfar mempunyai bentuk dasar ghafara. Jikaghafara bermakna menutup, lalu bagaimana cara memohon als\}afh \}ukepada Allah, agar catatan amal jelek kita dibuang dan diganti lembaran baru yang putih bersih? 
Al-Ghāfir adalah sifat-Nya yang menyembunyikan aib hamba-hamba-Nya agar mereka dapat hidup berdampingan, saling mempercayai, bekerja sama, mencintai, dan saling menghormati satu sama lain. Sebaliknya, jika Allah al-Ghāfir tidak menyembunyikan kesalahan-kesalahan kita, pendapat-pendapat yang merugikan, pikiran jahat, dan perasaan benci, niscaya akan menyebabkan setiap orang akan menjauhi satu sama lainnya. Tentunya, tidak akan ada keluarga atau masyarakat.

Selanjutnya, Allah al-Ghafūr menyembunyikan kesalahan-kesalahan kita di alam arwah dan malaikat persis seperti yang dilakukan-Nya di alam manusia. Para malaikat mampu melihat hal-hal yang tidak dapat kita lihat di dunia ini. Allah menyembunyikan kesalahan-kesalahan kita dari mereka agar kita tidak merasa malu di akhirat.

Nama Allah al-Ghaffār merupakan nama yang paling sempurna dalam ampunan. Orang yang kesalahan-kesalahannya disembunyikan dari orang lain berarti dilindungi dari rasa malu di depan mereka, namun dia tetap merasa malu kepada dirinya sendiri. Setiap orang merasakan penderitan karena perbuatannya. Dengan rahmat-Nya, Allah al-Ghaffār menyembunyikan kesalahan seseorang bahkan dari dirinya sendiri dan membuatnya jadi lupa dengan tujuan untuk meringankan penderitannya.

Al-Ghāfir adalah tirai penutup kesalahan-kesalahan kita dari penglihatan orang lain; al-Ghafūr yang menyimpan pengetahuan mengenai kesalahan-kesalahan kita bahkan dari para malaikat sekalipun; dan al-Ghaffār yang melapangkan hati kita dari penderitaan karena terus menerus mengingat kesalahan-kesalahan sendiri. ${ }^{45}$ Makna menutup dosa itu terbagi dua, yaitu menutup dari maksiat dan menutup dalam maksiat. Artinya, ketika seseorang sudah melakukan suatu kemaksiatan, maka Allah menutupnya dari pengetahuan manusia. Dan arti dari menutup dalam maksiat adalah, Allah tidak memberi kesempatan baginya untuk berbuat kemaksiatan. ${ }^{46}$

Dengan demikian, makna istighfar bisa disimpulkan sebagai ungkapan mengakui segala kesalahan yang telah dilakukan kepada Allah, seraya menyesal atas hal tersebut, diiringi dengan kemauan yang kuat untuk tidak mengulanginya lagi.

\footnotetext{
45 Tosun Bayrak, Asmā al-Husna>, ter. Nuruddin Hidayat (Jakarta: PT Serambi Ilmu Semesta, 2007), 152-153.

${ }^{46}$ Fadhlalla Haeri, Al-Hikam: Rampai Hikmah Ibn 'Athaillah, ter. Lisma Dyawati Fuaida (Jakarta: Serambi Ilmu Semesta, 2004), 133.
} 
Selanjutnya mengiringinya dengan perbuatan baik, dan tetap yakin akan luasnya ampunan Allah yang Maha Pengampun.

\section{Makna Kandungan Istighfar}

Dengan melihat berbagai macam bentuk istighfar diatas dan mencermati kandungan yang ada didalamnya, maka setidaknya istighfar itu memiliki kandungan atau semangat sebagai berikut;

1. Mengakui bahwa Allah-lah Yang Maha Suci dari dosa

Sesungguhnya manusia itu sangat ingkar, tidak berterima kasih kepada Tuhannya, dan Sesungguhnya manusia itu menyaksikan (sendiri) keingkarannya, (Qs. al-'A>diya $>t$ : 6-7)

2. Timbulkan sikap optimis atas rahmat Allah “....dan janganlah kamu berputus asa dari rahmat Allah. Sesungguhnya tiada berputus asa dari rahmat Allah melainkan kaum yg kafir." (Qs. Yu>suf : 12)

3. Berbaik sangka dan meningkatkan keyakinan serta optimis akan rahmat Allah.

Berprasangka baik kepada Allah merupakan salah satu dasar utama manusia membangun hubungan dengan Allah swt. Karena Allah swt. terhadap hambanya seperti yang hambanya sangkakan kepada-Nya, kalau seorang hamba berprasangka buruk kepada Allah swt. maka buruklah prasangka Allah kepada orang tersebut, jika baik prasangka hamba kepada-Nya maka baik pulalah prasangka Allah kepada orang tersebut.

Dari Abu Hurairah ra., ia berkata : Nabi saw. bersabda : "Allah Ta'ala berfirman: "Aku menurut sangkaan hambaKu kepada-Ku, dan Aku bersamanya apabila ia ingat kepada-Ku. Jika ia ingat kepada-Ku dalam dirinya maka Aku mengingatnya dalam diriKu. Jika ia ingat kepada-Ku dalam kelompok orang-orang yang lebih baik dari kelompok mereka. Jika ia mendekat kepadaKu sejengkal maka Aku mendekat kepadanya sehasta. jika ia mendekat kepada-Ku sehasta maka Aku mendekat kepadanya sedepa. Jika ia datang kepada-Ku dengan berjalan maka Aku datang kepadanya dengan berlarilari kecil“. (Hadits ditakhrij oleh Bukhari).

4. Mengakui Dosa-dosa

5. Timbulkan rasa hina di hadapan Allah

Dan Tuhanmu berfirman: "Berdoalah kepada-Ku, niscaya akan Ku perkenankan bagimu. Sesungguhnya orang-orang yang menyombongkan diri dari 
menyembah-Ku akan masuk neraka Jahannam dalam keadaan hina dina." (QS. Al Mu'min [40] : 60).

6. Jauh dari kesombongan

Dengan membiasakan diri beristighfar, seseoang akan menyadari bahwa dirinya diliputi dengan kekurangan. Tidak merasa bahwa ia yang terbaik. Tumbuh dalam dirinya sikap tawadhu'. Perlu diingat, bahwa Takabur atau sombong merupakan salah satu bentuk akhlak tercela yang sangat berbahaya bagi seseorang, khususnya seorang Muslim. Karena itu sifat takabur ini harus dijauhkan dari kehidupan seorang Muslim. Sifat takabur ini bisa muncul dalam diri seseorang karena merasa bangga dengan ilmu yang dimilikinya, atau bisa juga karena harta, kecantikan, kedudukan, dan lain sebagainya.

7. Semakin dekat dengan Allah

Istighfar adalah salah satu bentuk amal sholeh yang dianjurkan oleh Allah. Dengannya seorang hamba bisa mendekatkan diri kepada Allah. Salah satu hadith menyatakan, bahwa jika seseorang mendekatkan dirinya kepada Allah dengan salah satu ibadah sunnah, ia akan mendapat kecintaan Allah. Tentunya, hal ini berujung pada ridha-Nya.

Dari Abu Hurairah radhiallahu 'anh, ia berkata: Rasulullah shallallahu 'alaihi wa sallam "Sesungguhnya Allah ta'ala telah berfirman: 'Siapa yang memusuhi wali-Ku, maka sesungguhnya Aku menyatakan perang terhadapnya. Hamba-Ku senantiasa mendekatkan diri (taqarrub) kepada-Ku dengan suatu (perbuatan) yang Aku sukai seperti bila ia melakukan yang fardhu yang Aku perintahkan kepadanya. Dan hamba-Ku yang senantiasa mendekatkan diri (bertaqarrub) kepada-Ku dengan amalan-amalan sunnah maka Aku akan mencintainya. Jika Aku telah mencintainya, maka jadilah Aku sebagai pendengarannya yang ia gunakan untuk mendengar, sebagai penglihatannya yang ia gunakan untuk melihat, sebagai tangannya yang ia gunakan untuk memegang, sebagai kakinya yang ia gunakan untuk berjalan. Jika ia memohon sesuatu kepada-Ku, pasti Aku mengabulkannya dan jika ia memohon perlindungan, pasti akan Aku berikan kepadanya." HR Bukhari

8. Semakin bersyukur atas semua karunia

Orang yang senantiasa beristigfar akan selalu sadar, bahwa pintu ampunan Allah senantiasa terbuka. Terbuka pula pikiran dan hatinya, bahwa sebenarnya nikmat Allah yang diberikan bukan hanya ampunan saja, melainkan banyak nikmat 
yang tak terhitung jumlahnya. Dia-pun akhrinya menjadi lebih bersyukur karenanya.

9. Muhasabah diri

Sudah menjadi hal yang wajar, jika seseorang yang sungguh-sungguh dalam beristighfar akan senantiasa mengingat perilakunya yang telah lalu. menghitungnya, manakah yang lebih banyak? Dengan semangat makna istighfar yang ia ucapaka, perilakunya pun semakin membaik dan lebih baik lagi.

Khalifah Umar Ibnu Khaththab RA. memberikan nasihat : "Hisablah diri kamu sekalian sebelum dihisab oleh Allah. Dan berhias dirilah (dengan amal) untuk menghadapi ujian terbesar. Sesungguhnya penghisaban di hari kiyamat itu hanya akan terasa ringan bagi orang-orang yang terbiasa menghisab dirinya di dunia."

Imam Hasan Al-Basri mengatakan : "Sesungguhnya penghisaban dihari kiamat nanti akan ringan bagi orang yang telah menghisab amalnya didunia, begitu pula sebaliknya penghisaban dihari kiamat akan berat bagi orang yang tidak pernah menghisab amalnya didunia."

10. Visi yang Baik di hari mendatang

Dengan adanya muhasabah diri, seseorang akan terpacu untuk melihat dunia yang ia jalani, bukan hanya hari ini saja, tapi hari mendatang juga.

"Hai orang-orang yang beriman, bertaqwalah kepada Allah dan hendaklah setiap diri memperhatikan apa yang telah diperbuatnya untuk hari esok (akhirat), dan bertaqwalah kepada Allah, sesungguhnya Allah Maha Mengetahui apa yang kamu kerjakan." (QS. Al-Hasyr (59) : 18)

11. Akhlaq semakin membaik

Muhasabah pada prinsipnya adalah koreksi terhadap tindakan kita selama ini dan berusaha melakukan renovasi menuju akhlak yang lebih baik. Dan mengekang nafsu kita dari hal-hal yang berbau maksiat serta memaksakan diri untuk tunduk dan taat terhadap perintah Allah dan Rasul-Nya.

\section{Kesimpulan}

Dari penelitian akan hadith riwayat Ibn $\mathrm{Ma}>\mathrm{jah}$ yang menjelaskan tentang membiasakan istighfar dan keutamaan yang diberikan Allah kepada mereka sebagaimana sebelumnya, dapat diambil kesimpulan sebagai berikut: 
Pertama, hadith riwayat oleh Imam Ibn Ma $>$ jah membiasakan istighfar dan keutamaan yang diberikan Allah kepada mereka adalah $d l o{ }^{\prime} i>f$. Hal ini berdasar atas penilaian para kritikus hadith yang mengatakan bahwa al-H \}akam ibn Mus\}'ab adalah $m a j h u>l$. Hal ini secara otomatis menjadikan hadith tersebut tidak bisa dijadikan hujjah dalam sebuah hukum, apalagi yang berkaitan dengan al-Qur'an.

Kedua, pemahaman yang relevan terhadap hadith yang menjadi objek kajian penelitian ini, yang menyatakan bahwa barang siapa yang menekuni istighfar, Allah akan menjadikan dari setiap kesedihan kelonggaran, dan dari setiap kesempitan jalan keluar dan memberi rizki kepadanya dari arah yang tidak disangka-sangka, adalah bisa diterima maknanya. Dan hal tersebut tidak bertentangan dengan al-Qur'an maupun sunnah Rasulullah saw. Ini terbukti, ketika hadith tersebut dikaji dengan rinci sekalipun, ia juga sesuai dengan al-Qur'an. Tidak bertentangan dan bahkan sejalan dengan apa yang ada di dalamnya. Hadith-pun juga demikian, banyak sekali hadith yang menganjurkan setiap muslim untuk membiasakan istighfar, dan ini dicontohkan pula oleh Rasulullah saw. dalam kehidupan sehari-hari beliau. Terbukti juga, banyak ayat yang menjelaskan akan hikmah yang diturunkan oleh-Nya kepada mereka yang membiasakan istighfar, seperti turunnya rahmat, dosa yang dihapus, diberikan kemenangan, keburukan diganti kebaikan dan sebagainya. 


\section{DAFTAR PUSTAKA}

Al-Bukha>ri>, Ima>m. Shahih Bukhari. Mesir: Maktabah al-Iman, Tt.

Al-Ghazali, Imam. Raudah; Taman Jiwa Kaum Sufi, terj. M. Luqman Hakim, cet. II. Surabaya: Risalah Gusti, 1995.

Al-Jauziyyah, Ibn al-Qayyim. Madarijus-Salikin (Pendakian Menuju Allah), terj. Kathur Suhardi. Jakarta: Pustaka al-Kautsar, 1998.

Al-Muha>sibi>, Al- Ha>rith bin Asad. al-Taubah. Tk.: Da>r al- I'tis $\} a>m$, T.t.

Al-Qarni, Aidh. La> Tahzan, Jangan Bersedih. terj, Samson Rahman. Jakarta: Qisthi Press, 2005.

Al-Zubaidy, Muhammad Murtad\}a. Ta>j al 'Aru>sh jilid I. Mesir: al-Mut\}aba'a>t alKhairiyyah bi al-Jama>liyyah, T.th.

Da>wud, Abu.> Sunan Abi> Da>wud. Beirut: Da>r Ibn H\}azm, 1997.

Hadi, Sutrisno. Methodology Research. Yogyakarta: Andi Offset, 1994.

Isma'il, M. Syuhudi. Cara Praktis Mencari Hadis Nabi. Jakarta: Bulan Bintang, 1991.

Koentjaraningrat. Metode-metode Penelitian dalam Masyarakat. Jakarta: PT. Gramedia, 1997.

Ma'luf, Louis. Al-Munji $>d$ fi $>$ al-Lughah wa al- 'Ala $>m$. Beiru>t: Da>r al-Masyriq,Tt.

Manzur, Jama>1 al-Din Muhammad Ibn Mukarram Ibn. Lisa>n al- 'Arab, Jilid I . Beirut: $\mathrm{Da}>\mathrm{r}$ al- $\mathrm{S}\{\mathrm{adr}, \mathrm{t} . \mathrm{th}$.

Nasution, Harun. Dkk. "Dosa" dalam Ensiklopedia Islam Indonesia IAIN Syarif Hidayatullah. Jakarta: Djambatan, 1992.

Qardhawi, Yusuf. Bagaimana Memahami Hadis Nabi, terj. Muhammad al-Baqir. Bandung: Karisma, 1993.

RI, Departemen Agama. al-Qur'an dan Terjemahannya, cet, III . Semarang: Tanjungmas Inti, Tt.

Shihab, M. Quraish. Membumikan al-Quran. Bandung: Mizan,1996.

Tahhan, Muhammad. Taisi>r Must\}alah\} al-H\}adith. Surabaya: Syirkah Bungkul Indah, t.t. 